Bangladesh J. Zool. 41(1): 49-60, 2013

\title{
SHARKS AND RAYS FISHERIES OF THE BAY OF BENGAL AT THE LANDING CENTERS OF CHITTAGONG AND COX'S BAZAR, BANGLADESH
}

\author{
Bikram Jit Roy*, S.M. Hasan Ali, Nripendra Kumar Singha \\ and Md. Gaziur Rahman ${ }^{1}$ \\ Marine Fisheries Survey Management Unit, C.G.O. building-2, 6th floor, Agrabad, \\ Chittagong, Bangladesh.
}

\begin{abstract}
The study was conducted on the species composition and percentage contribution of sharks and rays from two landing centers (Fishery ghat, Chittagong and BFDC fish harbour, Cox's Bazar) during 2011-2012 fiscal year. A total 10 species of sharks belonging to 3 families and 14 species of rays belonging to 8 families were recorded. Total landings of sharks and rays by weight were 382.67 MT of which 136.45 MT was sharks and 246.22 MT was rays. A total 479661 numbers of sharks and rays were landed of which 449133 were sharks and 30528 were rays but contribution of sharks and rays were $35.66 \%$ and $64.34 \%$, respectively by weight. The highest landing was 70.94 MT in the month of October, 2011 and lowest landing was 6.05 MT in the month of January, 2012. The highest landing of shark species was Scoliodon laticaudus (84.52 MT) $(22.09 \%)$ and lowest was Carcharhinus sorrah (0.01MT) and the maximum and minimum landing of rays species were Himantura uarnak (164.42MT) (42.97\%) and Aetobatus narinari (0.03\% MT), respectively.

Key words: Sharks and rays, species composition, Bay of Bengal, Cox's Bazar, Chittagong
\end{abstract}

\section{INTRODUCTION}

In Bangladesh shark fisheries (sharks and rays) are mainly artisanal fisheries, it is exploited by the fishers as targeted species and as a by catch by other fisheries. Sharks are captured by shark net (modified large mesh gill net) and sometimes hooks (shark hooks) and line. Rays are mainly harvested by hooks and line but sometimes by the set bag net and trammel net also (Roy 2008). Large numbers of juvenile sharks and rays are caught incidentally by shrimp and fish trawls which remain unreported. Sharks and rays are targeted mainly for its high value fins but meat has some demand in the tribal area of the country. The most valuable shark fins and few dried meats are exported to different Asian countries.

The Republic has a $710 \mathrm{~km}$ long coastal line on the southern coastal zone of the country. In these areas fleets of small scale fishing craft and gears such as 44927 numbers of mechanized and non-mechanized boats and 223858 numbers

*Corresponding author: E-mail: jitroy1964@yahoo.com ${ }^{1}$ Matshya Bhaban, Dhaka, Bangladesh. 
of different types gears are engaged within 40 meters depth. For industrial fishing a total of 172 numbers different trawlers are harvesting beyond 40 meter depth. Commercially120-150 numbers of artisanal boats are engaged for sharks and rays fishing in Bay of Bengal. The multi-species coastal fisheries, at both artisanal and commercial levels, comprise of 56 species of sharks and rays (IUCN 2000). Day (1878) mentioned 63 species and Roy et al. (2011) identified 27 species of sharks (11 species) and rays (16 species) in the Bay of Bengal.

As many as, 70 species of sharks are found in Indian waters, though only 18 species are occasionally or frequently caught (Hausfather 2004). In Myanmar waters, only 36 species have been reported recently (SEAFDEC 2012). At present, 9 families of sharks (19 species) and 6 families of rays $(22$ species) have been recorded from Cambodia (SEAFDEC 2012).

In Sri Lanka the elasmobranches caught as a by catch from other fisheries by using bottom and drift gill nets, despite this, elasmobranches are important nationally, contributing $8.76 \%$ of the total catch during 1987-1991 (Bonfil 1994). Elasmobranches fisheries of Pakistan were of prime importance on a global scale until recently when production dropped significantly. The relative importance of Elasmobranches in Pakistan is among the highest in the world (Bonfil 1994). Sharks catches are incidental to other fisheries in India (Appukuttan and Nair 1988) and are mainly taken with long lines. Rays are caught with bottom set gill nets in Gujarat, North West India and Cudalore and are abundant on the outer shelf and slope off Karala and Karuatakta (Devadoss 1978). There have traditionally been important fisheries for elasmobranches in India with a relatively steady growth up to the mid seventies. Indian production of sharks and rays represent only $1.72 \%$ of the total national catch in 19871991 (Bonfil 1994). The large fisheries production of South Korea, elasmobranches are of minor importance representing only $0.66 \%$ of the total catch between 1987 and 1991 (Bonfil 1994).

Traditionally, elasmobranches have not been considered as highly priced fishery product. Their economic value rank low among marine commercial fisheries (e.g. in the Taiwanese gill net fisheries of the central waters pacific, shark prices attain only $20 \%$ and $60 \%$ of those of tunas and mackerels, respectively. The only highly priced elasmobranch product is shark fin for oriental soup, a commodity for which there has recently been a considerable increase in demand (Cook 1990). Since 1972 all sharks and rays used exhaustively for domestic consumption in Bangladesh but from few years back meats, fins, skin, jaws, vertebrae and liver oil are exported to Korea, Singapore, China, Hong Kong, Mayanmar, Thailand and other countries. 
Till now, there is no comprehensive report on the landing of sharks and rays in Bangladesh, Therefore, this study aims to provide an overview of landing trends, species composition and percentage contribution in shark fisheries producing and exporting from an economic and social point of view.

\section{MATERIAL AND METHODS}

The main two landing centers of sharks and rays situated at Fishery ghat, Chittagong and BFDC Fish harbour, Cox's Bazar district were selected for sampling in order to cover a wide range of the most sharks and rays landing retail and whole sale marketing, target and incidental catch of shark and ray species from the Bay of Bengal. The field visit was undertaken for a year starting from July, 2011 to June, 2012 at the mentionable two fish landing centers where only 80-100 numbers of boats are engaged for sharks and rays fishing commercially in the southern part of the Bay of Bengal fishing grounds.

Species-wise sharks and rays landing data were recorded at both landing station and on board commercial fishing vessels. In the selected sampling station elasmobranches catch data were collected by 5 Scientific Officer and 10 field staff alternately. The data were collected in new-moon, full-moon, first quarter, last quarter and other days of the moon month from the landing center. Sampling days were 8 in each month of the year continuously by the Marine Fisheries Survey Management Unit, Chittagong.

Species were identified locally and unidentified species were preserved in 5$7 \%$ formalin solution just after collection from the landing centers, brought to laboratory to find out lowest possible taxonomic level by the help of Munro (1955), Bonfil and Mohammad (2003), Quddus et al. (1988), Raje et al. (2007).

\section{RESULTS AND DISCUSSION}

A total 24 species of sharks and rays were identified in this study of which 10 were shark's species, they are Scoliodon laticaudus, Sphrna lewin, Rhizoprionodon acutus, Chiloscyllium indicum, Galeocerdo cuvier, Carcharhinus melanopterus and C. falciformis, Rhizoprionodon acutus, Carcharhinus leucas and C. sorrah of which the most common and widely distributed two sharks species were Scoliodon laticaudus and Sphrna lewini, five species were (Rhizoprionodon acutus, Chiloscyllium indicum, Galeocerdo cuvier, Carcharhinus melanopterus and C. falciformis) moderately abundant and rarely found species were Rhizoprionodon acutus, Carcharhinus leucas and C. sorrah.

The 14 species of rays are Himautura uarnak, $H$. uarnacoides, $H$. gerrardi, $H$. undulata, Rhinobatos typus, Gymnura japanica, Aetomylaeus nichofii, 
Rhynachobatus laevis, Aetobatus narinari, Rhinoptera javanica, Rhina ancylostoma, Urogymnus asperrimus, H. walga and Mobula kuhlii. Among them Himautura uarnak, H. uarnacoides, Rhinobatos typus were the most common species. Moderately abundant fished rays were Gymnura japanica, Aetomylaeus nichofii and Rhynachobatus laevis and limited occurrence of species were Aetobatus narinari followed by Rhinoptera javanica, Rhina ancylostoma, Urogymnus asperrimus, Himantura gerrardi, H. undulata, H. walga and Mobula kuhlii.

A total 382.67 MT of sharks and rays were landed by weight during the study period. Among them total harvested sharks and rays landing weight were 136.45 MT and 246.22 MT, respectively. The month wise composition is given in Fig. 1.

Species wise landing by weight showed that, Scoliodon laticaudus was 84.52 MT followed by Rhizoprionodon acutus, R. oligolinx, Sphyrna lewini, Chiloscyllium indicum, Galeocerdo cuvier, Carcharhinus melanopterus, C. leucas, C. falciformis and $C$. sorrah which were $5.56,0.02,27.08,4.48,5.13,4.77,1.15,3.37$ and 0.01 MT, respectively (Table 1). Total landing weight of ray's species Himautura uarnak was 164.42 MT followed by

H. uarnacoides (33.29 MT), Rhinobatos typus (27.16 MT), Gymnura japanica (10.0 MT), Aetomylaeus nichofii (3.37 MT), Rhynachobatus laevis (2.30 MT), Mobula kuhlii-(1.72 MT), H. walga (1.18 MT), H. undulata (0.89 MT), H. gerrardi (0.78 MT), Urogymnus asperrimus (0.67 MT), Rhinoptera javanica (0.32 MT), Rhina ancylostoma (0.09 MT) and Aetobatus narinari (0.03 MT) of the total catch (Table1).

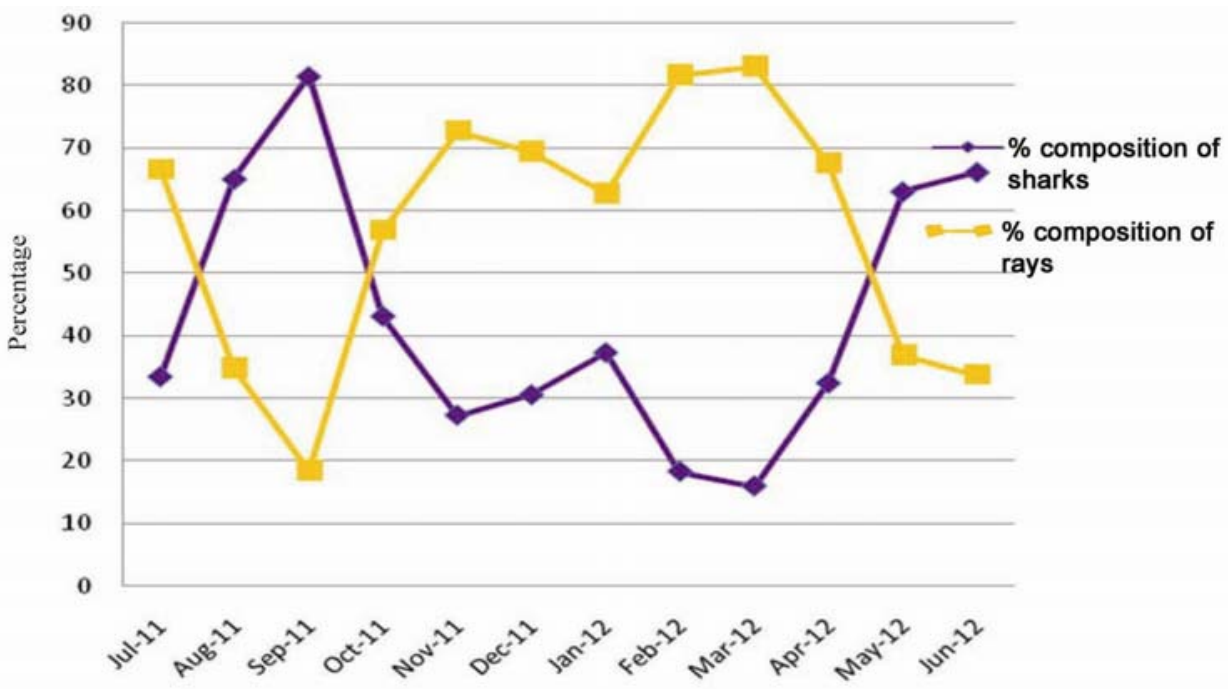

Fig. 1. Monthwise percentage composition of sharks and rays at Chittagong and Cox's Bazar landing centers 
The month wise landing weight of shark's in total 4.99 MT of sharks was landed in the month of July 2011 followed by 11.65 MT, 10.37 MT, 30.60 MT, 16.45 MT, 18.79 MT, 11.68 MT, 6.81 MT, 5.29 MT, 7.55 MT, 8.09 MT and 4.00 MT in August,11, September,11, October,11, November,11, December,11, January,12, February,12, March,12, April,12, May,12 and June,12 respectively (Fig. 4). And in the month of July,2011 total landed weight of rays was 9.94 MT followed by August,11, September,11, October,11, November,11, December,11, January,12, February,12, March,12, April,12, May,12 and June,12 were 6.25 MT, 2.35 MT, 40.34 MT, 43.88 MT, 42.70 MT, 19.94 MT, 30.42 MT, 27.88 MT, 15.74 MT, 4.74 MT, and 2.05 MT respectively (Table 1).

Total 479,661 numbers of juvenile and adult sharks and rays were harvested during July, 2011 to June, 2012 (Table 2). Among them total species number of sharks was 449,133 . Month wise maximum number of landed sharks was 135,177 in the month of October, 2011 and minimum landed number was 9803 in March, 2012. Total 30,528 number of ray's species was landed during the study period, month wise harvested highest and lowest number of rays were 6,797 and 252 number in the month of October, 2011 and June,2012 respectively (Table 3).

Shown this in a Table 3 in the species wise analyzing total landed number of shark species Scoliodon laticaudus was 420,365 numbers followed by Rhizoprionodon acutus, $R$. oligolinx, Sphrna lewini, Chiloscyllium indicum, Galeocerdo cuvier, Carcharhinus melanopterus, C. leucas, C. falciformis and C. sorrah were 3519, 10, 15924, 4832, 304, 74, 641 and 05 numbers respectively. Species wise total number of ray species Himautura uarnak was 16982 in numbers followed by 84, 45, 36, 2964, 5182, 36, 1704, 442, 2925, 74, 43,3 and 8 numbers in $H$. walga, $H$. undulata, $H$. gerrardi, $H$. uarnacoides, G. japanica, $R$. javanica, A. nichofii, $M$. kuhlii, $R$. typus, $R$. laevis, $R$. ancylostoma, A. narinari and $U$. asperrimus, respectively.

In average percentage contribution of the total sharks constituted $35.66 \%$ of the total catch by weight and the rest $64.34 \%$ was in rays. Species wise average percentage contribution of the shark species $S$. laticaudus was $22.09 \%$ followed by $R$. acutus $-1.45 \%, R$. oligolinx $-0.0 \%$, S. lewini-7.08\%, C. indicum-1.26\%, G. cuvier-1.34\%, C. melanopterus- $1.25 \%$, C. leucas-0.30\%, C. falciformis- $0.88 \%$ and C. sorrah was zero\% of the total landing. And among the ray species Himantura uarnak was $42.97 \%$ followed by $H$. walga, $H$. undulata, $H$. gerrardi, $H$. uarnacoides, Gymnura japanica, Rhinoptera javanica, Aetomylaeus nichofii, Mobula kuhlii, Rhinobatos typus, Rhynachobatus laevis, Rhina ancylostoma, Aetobatus narinari and Urogymnus asperrimus were 0.32, 0.23, 0.20\%, 8.70, $2.61,0.08,0.88,0.44,7.10,0.60,0.02$, zero and $0.18 \%$, respectively (Table 2). 


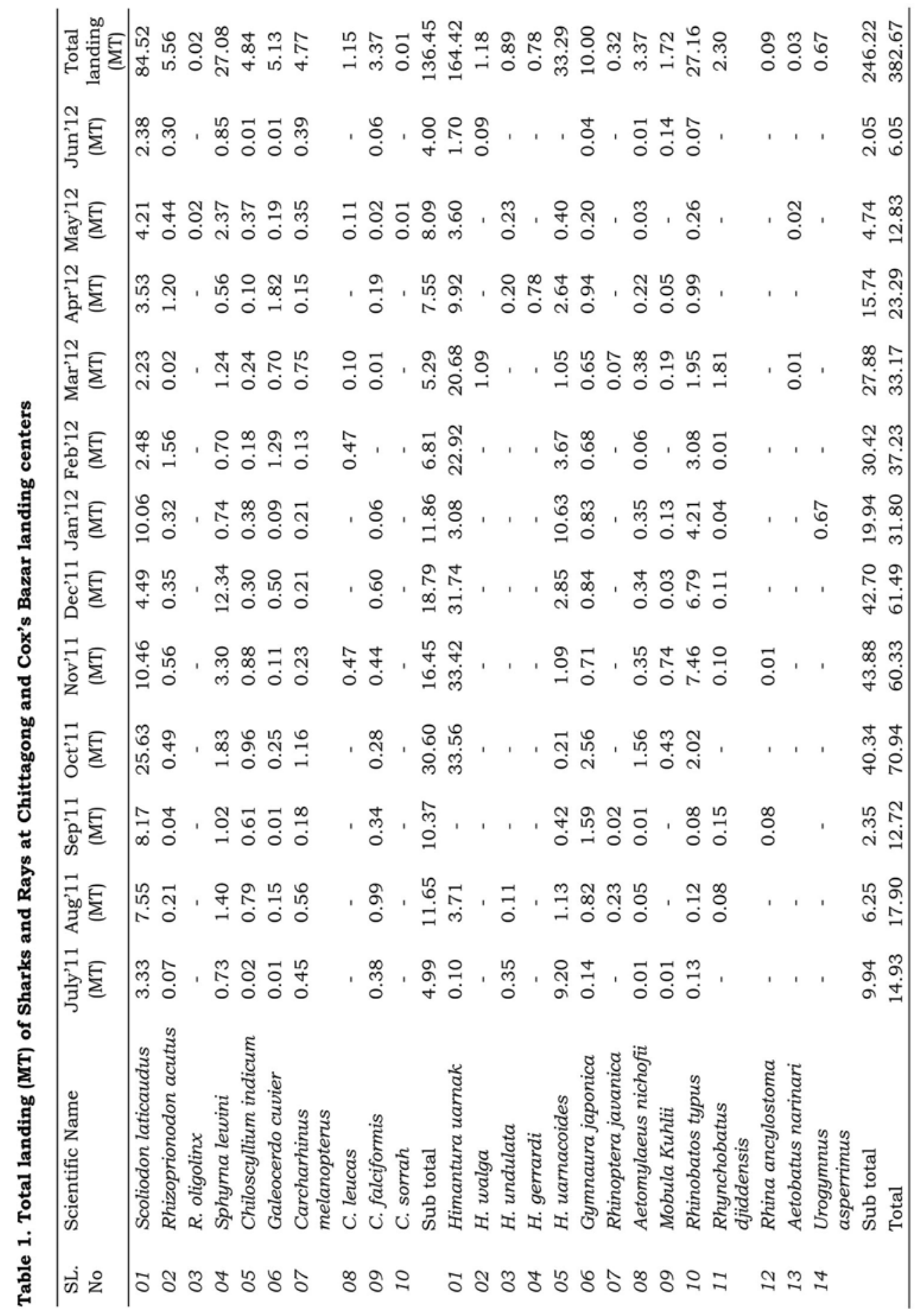




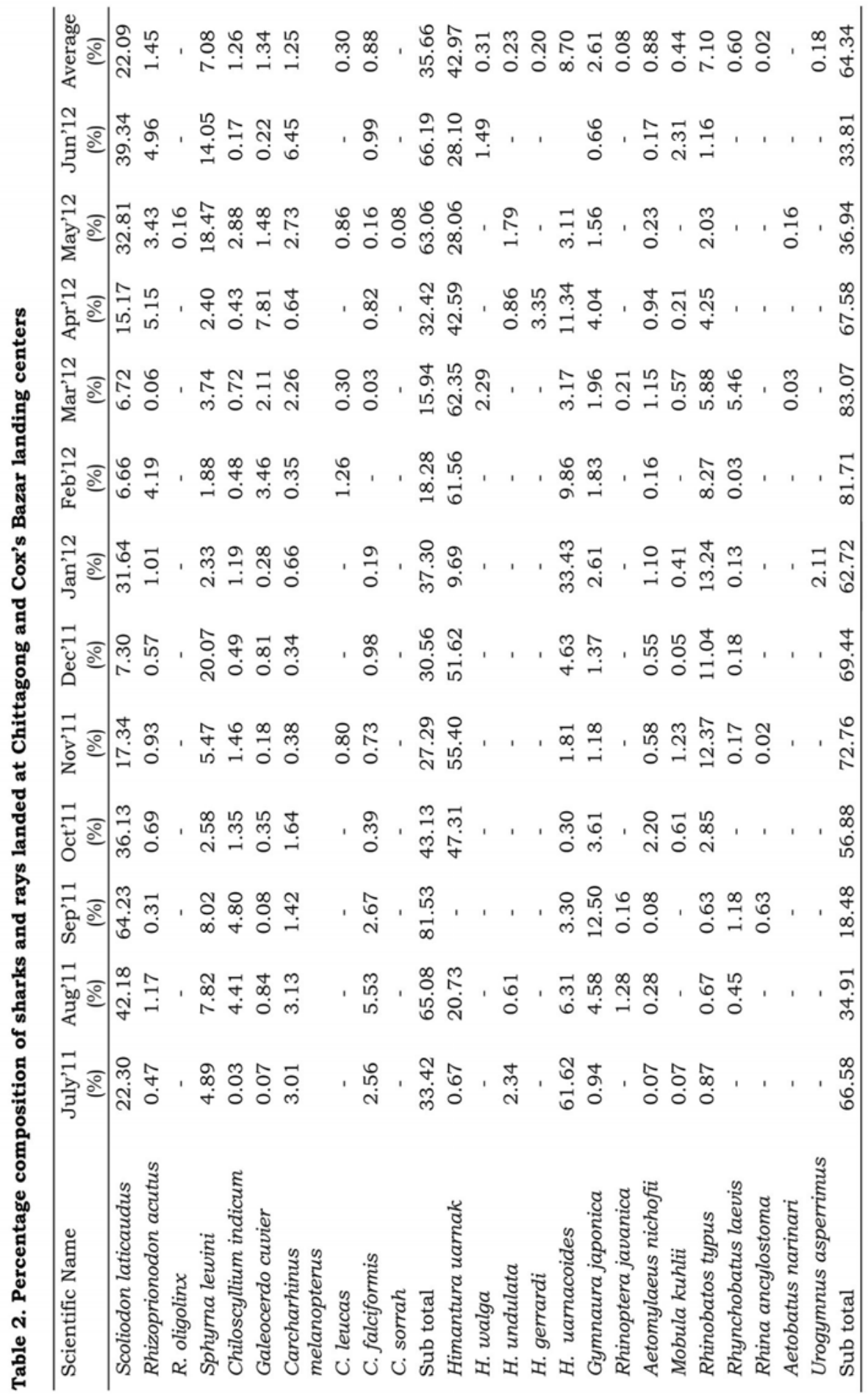




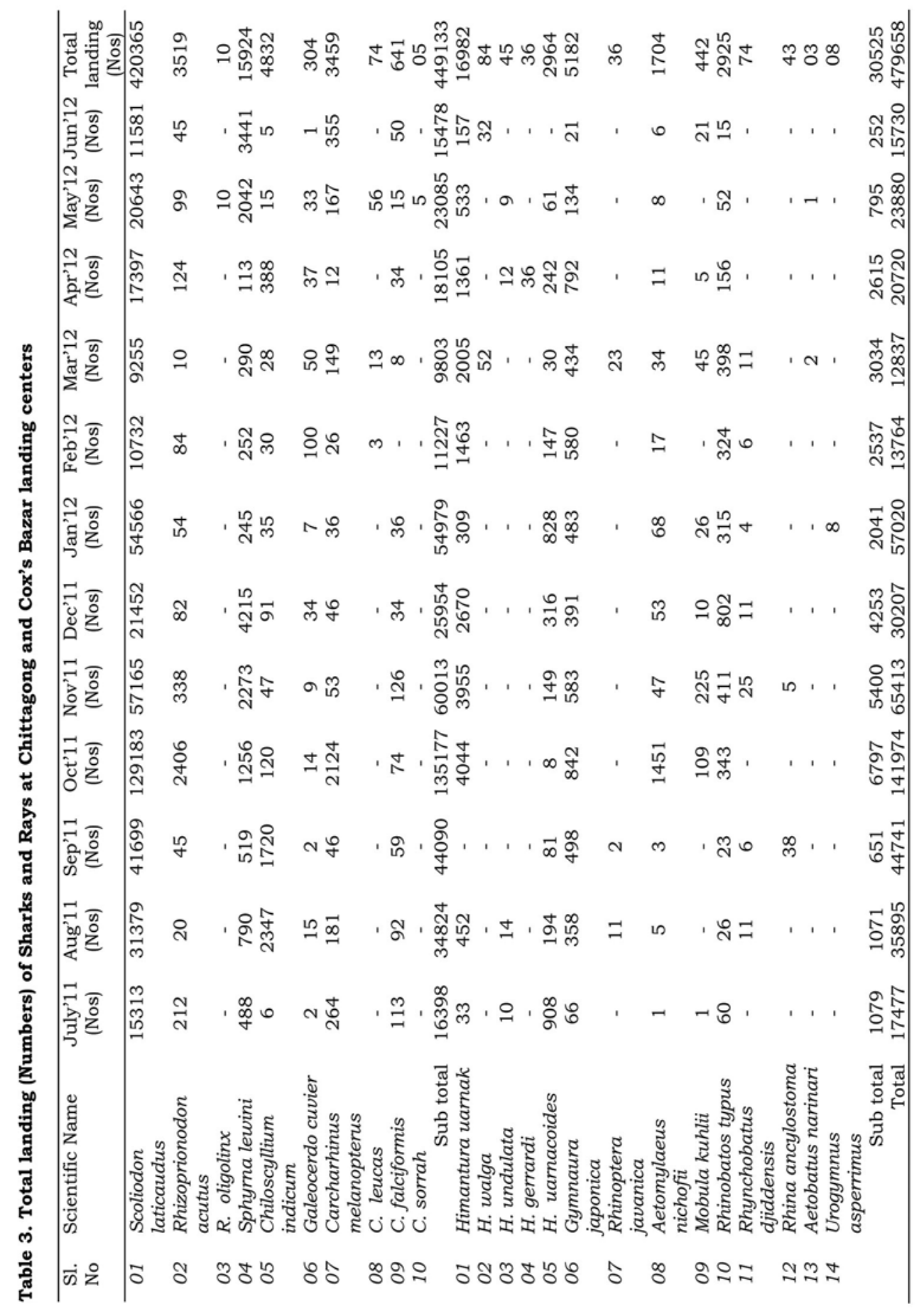


Month wise highest and lowest percentage contributions of sharks were $81.53 \%$ and $15.94 \%$ in the month of September, 2011 and March, 2012 respectively and in rays fished the month wise maximum and minimum percentage contribution were $83.07 \%$ and $18.48 \%$ in the month of March, 2012 and September, 2011 respectively (Table 2).

During 2005 total world fish production was 93253346 MT and the sharks and rays production was contributed $0.83 \%$ (FAO, 2005). According to the FAO (2007), total marine fish production was 65709000 MT and the sharks, rays and chimaeras were 771105 MT (1.17\%).

In the year 2010-2011 period total marine fish production of Bangladesh was 54,633 MT of which sharks, skates and rays contributed $0.77 \%(4,205$ MT) only in artisanal fishing and $0.13 \%$ of the total country fish production $(30,61,687$ MT) (DOF 2012). But in the present study period 10 sharks species and 24 rays species were recorded and their total landing volumes was 382.67 MT which contributed only $9.10 \%$ of the total shark production of Bangladesh

Shark fining, the practice of catching a shark, slicing off its fins and then discarding the body at sea takes a tremendous toll on shark populations, up to 73 million sharks are killed every year to primarily support the global shark fin industry, valued for the Asian delicacy shark fin soup (Alone 2011).

Statistics for the elasmobranches fisheries of Indonesia were not recorded before 1971. Indonesia fisheries represent $10.18 \%$ of the world's elasmobranches catch. Despite this, elasmobranches are of only moderate importance in Indonesia, contributing $2.41 \%$ to Indonesian landings during 1987-1991(Bonfil, 1994). Artisanal shark and ray fisheries in eastern Indonesia including Java, Bali, Nusa, Tenggara and Papua, a total of 137 species of chondrichthyans consisting of 78 sharks, 56 rays and 3 chimaeras were formally recorded to occur in Indonesian waters; the annual production of sharks was 45832 MT and 61663 MT of rays and sharks and rays productions were contributed $0.94 \%$ and $2.26 \%$ respectively from the total production during 2009 (Faizah 2012).

There are 7 orders of sharks comprising of 62 species (18 families), 6 orders of rays comprising of 79 species (15 families) and one species of chimaeras inhabiting Malaysian waters from freshwater to deep sea and total production of sharks was $7253 \mathrm{MT}$ and rays was $15091 \mathrm{MT}$ and their contribution only $1.71 \%$ (sharks- $0.50 \%$ and rays $-1.10 \%$ ) of the total marine fisheries production during 2009 (SEAFDEC 2012).

In Thailand for large scale activity used purse seines, trawl, and hook and line but in small scale activity used gill/drift net and hook/long line for Elasmobranch fishery. Total 60 species of sharks and 60 species of rays have 
been found in the Thai waters and total production of sharks was 2862 MT and 6219 MT rays and represents of sharks $0.20 \%$ and rays $0.50 \%$ (average, $0.29 \%$ ) were of the total marine fisheries landing during 2009 (SEAFDEC 2012).

This study reveals that total production of elasmobranchs in South Korea, Thailand and Philippines represents only less than $1 \%$ of the total marine fish production which is similar to Bangladesh. Shark fisheries production (\%) But in Malaysia, Indonesia, Sri Lanka, India and Pakistan total landing of elasmobranch was more than $1 \%$ of the total marine fisheries landing. In this study a total 24 species of sharks and rays were recorded during one year study period; harvested 479661 numbers of sharks and rays species and their total landing of weight was $382.67 \mathrm{MT}$ of which sharks and rays contribute $35.66 \%$ and $64.34 \%$ respectively. Roy (2008) previously mentioned that the exploitation of shark fishing is seasonal but harvest start from November continue up to May, the peak period of harvest in December to January. But in this study the peak period of exploitation on sharks and rays fishing were found in October to December.

Roy et al. (2007) described that during April, 2006 to March, 2007 total 22 species of sharks, skates and rays were identified and total 162888 numbers of sharks, skates and rays species were harvested and their total landing weight was 398.68 MT, the highest sharks and rays catch were Scoliodon sorrakowah (34.415MT, 8.63\%) and Himantura uarnak (163.904MT, 41.11\%) respectively. But in the present study a total of July, 2011 to June, 2012 period total 24 species of sharks and rays were recorded, their total exploited numbers was 479658 and total landed weight was $382.67 \mathrm{MT}$; the highest catch of sharks and rays were Scoliodon laticaudus (sorrakowah) (84.52MT, 22.09\%) and Himantura uarnak (164.97MT, 42.97\%) respectively of the total landing. According to the Roy et al. (2007), analyzing and this study, total catch numbers of sharks and rays species variety and total landing weight about same but total exploited species numbers about 3 times more remaining the Roy et al. (2007) study at the same landing stations. Halder (2010) mentioned that catches of small size juvenile sharks has increased with the decrease of large size shark and some species are rare in the catches. So it is clear that small sizes of juveniles' sharks and rays species are harvested which is an indication of danger for future shark fisheries.

The major problem on shark and ray fisheries are the lack of catch and species composition data, as most fisheries doesn't report shark landings by species and lack of species identification knowledge of shark. No information on biological data or size compositions of species landed, stock assessment for 
sharks in Bangladesh has never conducted. For proper management and conservation of shark fisheries there is need for a National Action Plan (NAP).

\section{LITERATURE CITED}

ALONE 2011, Shark catch data..http//www.livescience.com/1027.shark slaughter, and Global Shark Conservation. Link: http// www.PewEnvironment.org/sharks,

APPUKITTAN, K.K and NAIR K.P. 1988. Shark resources of India, with notes on biology of a few species. Managalore Karnatak; pp.173-183.

BONFIL, R. and MOHAMED A. 2003. FAO Species Identification Guide for fishery purposes. Field Identification Guide to the Sharks and Rays of Red Sea and Gulf of Aden, Jeddah, Rome.

BONFIL, R 1994. Overview of World elasmobranch fisheries. FAO Fisheries Technical paper 341, Instituto Nacional de la Pesca, Progreso, Yucatan, Mexico, 1.27, 106pp, Rome.

COOK, S.F.1990. Trends in shark fin markets: 1980, 1990 and beyond, Chondros 2(1): 3-6.

DAY, F. 1878. The fishes of India Being a natural / history of the fishes known to in habit the Seas and Fresh water of India, Burma and Ceylon Vol-1, Bernard Qualitch, London, UK

DEVADOSS, P.1978. On the food of rays, Dasyatis uarnak, D. alcockii and D. sephen. Indian J. Fish 25: 9-13.

DOF, 2012. Fisheries Statistical Year Book of Bangladesh, Department of Fisheries, Matshya BhabanDhaka, Bangladesh, 33p

FAO 2005. World fish production, FAO catch Statistics, World catches 1950-2005, Link: http://en.wikipedia.org/wiki/world_fish_production.

FAO 2007.World fish production, http://en.wikipedia.org/wiki/File:world_marine_fisheries_ capture_2007.png.

FAIZAH, R 2012. Shark information collection in Indonesia, Research Centre for fisheries Management and Conservation, Patra Jasa Building, JI. Gatot Subroto, Kav. 32-34, South Jakarta-12905.

HALDER, G.C. 2010. National Plan of Action for Shark Fisheries in Bangladesh. pp. 75-89. In: Hussain, M.G.and Hoq, M.E.(eds), Sustainable Management of Fisheries Resources of the Bay of Bengal. Support to BOBLME project, Bangladesh Fisheries Institute, Bangladesh. 122 p.

HAUSFATHER, Z. 2004. India's Shark Trade: An Analysis of Indian shark landing based on shark fin exports, Grinnell collage, Lowa.

IUCN 2000. Red book of threatened fishes of Bangladesh. International Union for Conservation of Nature (IUCN), Bangladesh Country office, Bangladesh, 116 p.

MUNRO, I.S.R. 1955. The Marine and Fresh water fishes of Ceylon. Dept. of External Affairs, Canbera, $349 \mathrm{p}+56$ pls.

QUDDUS M.M.A, SARKAR, M.N. and BANERJEE, A.K. 1988. Studies of the Chondrichthyes Fauna (sharks, skates and rays) of the Bay of Bengal. The Journal of Noami. 5(2): 19-23.

RAJE, S.G, SIVAKAMI, S, RAJ, G.M, KUMAR, P.P.M, RAJU, A. and JOSHI, K.K. 2007. An Atlas on the elasmobranch fishery resources of India, CMFRI special publication, number, 95.

ROY, B.J. 2008. Shark Fisheries Exploitation, Trade and Conservation of Bangladesh. Presented in the Convention on Migratory Shark (CMS) 2 $2^{\text {nd }}$ meeting, Held on December, 2008 at FAO head quarter, Rome, Italy. pp. 2 
ROY, B.J., ALAM F.M., RHAMAN, G.M., SINGHA, N.K. and AKHTAR, A. 2011. Landing trends, species composition and percentage contribution of sharks and rays in Chittagong and Cox's Bazar, Bangladesh. Journal of Marine Sciences and Fisheries, Chittagong University, Chittagong, Bangladesh 2: 6

ROY, B.J, DEY, M.P, ALAM, M.F. and SINGHA, N.K. 2007. Present status of shark fishing in the Marine water of Bangladesh, Presented in the Convention on the Conservation of Migratory Species (CMS) 1st Meeting in Seychelles. December, 2007.Link: www.UNEP/CMS/ MS/ Inf/ $10.4 \mathrm{p}$.

SEAFDEC. 2012. Report of the special meeting on sharks information collection in South East Asia, South East Asian Fisheries Development Center Training Department, Bangkok, Thailand.

(Manuscript recived on 22 November 2012 revised on 19 May 2013) 